\section{Trade War between the USA and China: Impact on an Austrian Company in the Steel Sector}

\author{
Thomas Scheipl \\ Rosengasse 4, 8605 Kapfenberg, Austria \\ thomas.scheipl@gmx.at
}

\section{Vito Bobek}

University of Maribor, Faculty of Economics and Business, Slovenia vito.bobek@um.si

\section{Tatjana Horvat}

University of Primorska, Faculty of Management, Koper, Slovenia

tatjana.horvat@fm-kp.si

\begin{abstract}
The paper is intended to provide information on the trade war between China and the USA. It analyses the consequences of the trade dispute, discusses the impact on an Austrian company in the steel sector, gives an overview of possible strategies with which companies can reduce the negative effects of tariffs and discusses strategies that are good options for companies in the steel industry. The methodology applied included theoretical and empirical research based on quantitative analysis as well as quantitative research in the form of expert interviews. The results show that the trade war between China and the USA was in full swing until January 2020. The impacts do not only affect the parties involved, but also other parties such as the EU. Companies can use a variety of strategies to mitigate the negative effects of trade wars. The best strategy for a company depends on the structure of the company, its products and its competitors. The paper adds new insights to the existing literature on the trade war between China and the US and its effects, strategies to mitigate the negative effects of tariffs and discussions on optimal strategies for companies in the steel industry.
\end{abstract}

Keywords: trade war, China, USA, tariffs, EU, strategies

\section{Introduction}

Today, China and the USA are the two largest economies in the world. There have been problems in the economic relations between the two countries for some time now (Noland, 1996). The economic rise of China has increasingly worried the Americans. They accuse the Chinese of stealing jobs in the US, deliberately undervaluing their currency - the yuan - exporting deflation by selling at unfair prices, keeping labour costs low by violating human rights and failing to meet commitments made to the WTO. Multinational companies operating in the US and China are already feeling the effects of the trade war, which luckily has already passed the peak after the signing by both sides of the agreement to
ORIGINAL SCIENTIFIC PAPER

RECEIVED: SEPTEMBER 2019

REVISED: JANUARY 2020

ACCEPTED: FEBRUARY 2020

DOI: 10.2478/ngoe-2020-0004

UDK: 339.5: 339.543(510:73:436)

JEL: F13, F51

Citation: Scheipl, T., Bobek, V., \& Horvat, T. (2020). Trade War between the USA and China: Impact on an Austrian Company in the Steel Sector. Naše gospodarstvo/Our Economy, 66(1), 39-51. DOI: 10.2478/ngoe-2020-0004

\section{NG OE}

\section{NAŠE GOSPODARSTVO OUR ECONOMY}

\begin{tabular}{l|l|l|} 
Vol. 66 & No. 1 & 2020 \\
\hline
\end{tabular}

pp. $39-51$ 
ease the trade war in mid-January 2020. Apple is planning a revision of its supply chain and has asked some of its major suppliers, such as Foxconn Inventec Corp or Goertek, to determine the impact on the cost of relocating parts of their current production in China to South-East Asia. The company sees the danger of being heavily dependent on the production in China and believes the risk is growing (Reuters, 2019a).

The Division Voestalpine High Performance Metals (HPM) has two clearly defined business areas: production and value-added services. Products include high-speed steel, nickel-based alloys, special steels, structural steel, valve steel, steels produced by force metallurgy and tool steels. In addition, the company produces drop forgings, such as low-alloy steels or titanium alloys. There are eight production facilities worldwide, in Austria, Sweden, Germany, USA and Brazil, as well as 160 sales companies in 40 countries. Several sales companies are located in China. Therefore, the trade war between the two nations directly and indirectly affects the division.

The aim of this paper is to provide an overview of the trade war between the USA and China, to examine the impact of the tariffs already imposed, and to analyse how the Voestalpine HPM Division is affected by the trade dispute and what strategies companies can use to mitigate the negative effects of the tariffs. The work is intended to answer the following research questions:

RQ1: What has been the general impact of the trade war between the US and China so far between July 2018 and December 2019?

RQ2: How is the Voestalpine HPM Division affected by the trade war between the USA and China?

RQ3: What strategies can companies use to mitigate the negative effects of tariffs? Are there optimal strategies for companies in the steel industry?

First, relations between the US and China are discussed, followed by an analysis of the development of trade between the two countries since the announcement of the tariffs and the impact of these tariffs. The following text will deal with trade between the EU and China, strategies to reduce the impact of tariffs and the impact on the Voestalpine HPM Division. Later, the text will explain the methodology used and the limitations. The final chapter deals with the results and the discussion, combining information obtained from the literature with empirical results.

The work combines theoretical analysis, which includes an extensive literature review, with empirical research, which is divided into a quantitative and a qualitative part. For the quantitative research, a statistical analysis is used, and the qualitative part consists of interviews. While the objective of the statistical analysis is to determine the impact of US tariffs, the interviews are intended to provide suggestions for possible strategies to mitigate the impact of tariffs.

\section{Literature Review}

The belief that free international trade is beneficial to all is widespread among people all over the world. But if this is the case, why is there a trade policy or even a trade war? Trade literature has provided several theoretical explanations for trade policy. "The most popular explanations are imperfect competition, rising yields, terms of trade argument, distributional effects and other WTO and national security-related reasons" (Qiu, Zhan \& Wei 2019, p. 154).

The Ricardian model and Heckscher-Ohlin models predict that countries will export products to industries with comparative advantages or abundant endowment with production factors. In recent decades, however, we have experienced a change in the structure of trade. One of the most important features is the emergence and growth of intra-industrial trade. With rising returns, new entrants cannot compete with the incumbents. Industries with economies of scale tend to have limited competition, leading to imperfect competition, such as monopolistic competition. These situations give governments leeway to help their companies increase their size to compete with foreign firms and to gain monopoly power to gain more advantages. As noted in the seminal work of Krugman (1987, 134): "However, if rising yields and imperfect competition are necessary components of the explanation of international trade, we live in a second-best world where government intervention can fundamentally improve market outcomes." Specifically, Krugman (1987) summarises two main arguments for trade policy: foreign trade and strategic trade policy.

The main argument of strategic trade policy is that, with rising returns and imperfect competition, protection can lead to some industries achieving higher returns than the opportunity cost of the resources they use. In industries with oligopolistic competition, because the companies achieve positive rents, a government can pursue an appropriate trade policy to influence the strategic interaction between domestic and foreign competitors in such a way that the profits of domestic companies can be increased at the expense of foreign companies in quantity competition or consumers in price competition. Spencer and Brander (1983) and Brander and Spencer (1985) affirm that, under 
the right circumstances, government policy can deter foreign companies from competing for profitable markets. A simple numerical example from Krugman (1987) can help to clarify intuition.

In addition to the basic market structure argument, the traditional terms of trade arguments also speak in favour of trade policy. For a large country that is able to influence the prices of foreign exporters, an import duty has the potential to increase its trading conditions. An import duty induces two opposing forces. On the one hand, the tariff distorts the country's production and consumption and thus reduces overall welfare. On the other hand, if the country is large, customs duties lower the price of imports, thereby winning the terms of trade. If the terms of trade profits dominate the loss due to the distortion, the overall prosperity of the country is increased by the import duty. The above analysis also refers to the trade deficit argument, which has been used by President Trump. As far as we know, the trade deficit is not considered in the literature to be the reason for a trade war; instead, the trade deficit is rather the result of an import duty. However, if one country (the US) improves its trading conditions by imposing an import duty, the country will import less and may eventually reduce its trade deficit. However, because of the retaliatory measures, the strategy of using import duties to reduce the trade deficit appears to be difficult to succeed. Stiglitz (2018) also argues that the multilateral trade deficit is important, not the bilateral deficit, which is mainly determined by macroeconomics the gap between domestic savings and investment - and not by trade relations between the US and China.

\section{Objectives of the US tariffs and recent escalation}

During the 2016 presidential campaign, President Trump talked about plans to combat trade practises that he considers unfair, citing Section 201 and Section 301 of the US Trade Act (Reuters, 2019c). These two sections currently play an important role and are therefore worthy of closer examination.

The US International Trade Commission (USITC) provides a detailed explanation on Section 201: “The USITC shall determine whether an article is imported in such increased quantities as to cause or threaten to cause serious injury to a US industry producing a similar article or directly competing with the imported article” (United States International Trade Commission, 2019).

Meanwhile, Section 301 of the Trade Act of 1974 empowers the US Trade Representative to take action if certain rights granted to the US by trade agreements are violated (Govinfo, 2018).
In March 2017, two months after taking office, Donald Trump signed two execution orders. The first calls for stronger enforcement of duties in both anti-dumping and anti-subsidy cases. The second aims to examine the causes of the US trade deficits. Just one month later, the US president met with the Chinese president Xi Jinping where both sides agreed on trade talks. However, the negotiations did not go well as no agreement could be reached on the US trade deficit. After that, the first serious action was taken against Beijing in the form of a probe under section 301 to investigate the potential theft of intellectual property by the Chinese. In March 2018, duties of $25 \%$ on steel and $10 \%$ on aluminium were imposed on Chinese imports. China reacted with tariffs of $25 \%$ on more than 100 products. Unfortunately, the fight did not stop there. Both sides have further increased tariffs. The Trump administration took its biggest measure on September 24, 2018, when it introduced tariffs of $10 \%$ on Chinese goods worth about 200 billion dollars. In addition, the administration announced that these tariffs would be increased to 25\% by the beginning of 2019 . Beijing reacted quickly and increased customs duties on US imports to a value of around 60 billion dollars. Although both sides agreed to stop the new tariffs, in May 2019, President Trump declared his intention to implement his previous plan to raise tariffs to 25\% (Reuters, 2019c).

\section{Economic impact of increased tariffs on the US and China}

$50 \%$ of all US imports from China in 2018 were affected by the increased US tariffs. Average tariffs on these imports are now up to $12 \%$ from the previous $3 \%$. China's retaliatory measures affect $70 \%$ of all imports from the USA and result in average tariffs of 18\% (Bown, 2019, p. 2).

In 2018, the USA exchanged goods and services with China worth 737.1 billion dollars. Imports amounted to 557.9 billion dollars and exports to 179.3 billion dollars. The total trade deficit of the USA, including goods and services, was therefore about 378.6 billion dollars. China is the USA's largest trading partner for goods. The USA imported goods worth 539.5 billion dollars, while exports amounted to 120.3 billion dollars. The trade deficit in goods was 419.2 billion dollars. Trade in services presents a different picture with a US surplus of 40.5 billion dollars (Office of the United States Trade Representative, 2019b).

US exports of goods to China have fallen by more than $7 \%$ compared to 2017. Nevertheless, China is the third largest export destination, accounting for $7.2 \%$ of total US exports. The main export categories are: vehicles ( $\$ 9.4$ billion), optical and medical instruments ( $\$ 9.8$ billion), electrical machinery (\$13 billion), machinery ( $\$ 14$ billion) and 
aircraft ( $\$ 18$ billion). Meanwhile, exports of services rose by $2.2 \%$ compared to 2017 , and with a total value of 58.9 billion dollars, exports of services have almost tripled since 2008. The transportation sector, intellectual property sector and trade sector are the leading services exported to China. The Ministry of Commerce estimates that, in 2015, more than 900,000 jobs were supported by exports to China. Exports of goods supported 600,000 jobs and exports of services accounted for the remaining 300,000 jobs (Office of the United States Trade Representative, 2019b).

In 2018, China was the most important source of merchandise imports for the USA. US merchandise imports have increased by $6.7 \%$ compared to 2017 . Overall, $21.2 \%$ of all US imports come from China. Leading import categories are: plastics (\$19 billion), toys and sports equipment (\$27 billion), furniture and bedding (\$35 billion), machinery (\$117 billion) and electrical machinery (\$152 billion). Imports of services increased by $5.5 \%$ to 18.4 billion dollars in the same year. The most imported services are related to travel, research and development, and the transport sector (Office of the United States Trade Representative, 2019b).

Global growth has so far had little impact, but recent events could have serious consequences for financial markets and the economy, and could potentially disrupt global supply chains. The most recent escalation was the increase from $10 \%$ to $25 \%$ in US tariffs on $\$ 200$ billion worth of imports from China and the announcement of retaliatory measures by the Chinese government.

Trade data seems to show an existing influence of previous tariffs imposed by the US and consequently by China. While the USA and China are directly involved in the trade war, their trading partners are also feeling the consequences of rising customs duties. However, there was an advanced increase in imports of goods in cases where customs duties were not implemented immediately after their announcement. It is likely that the importers were responsible for the decrease in imports after the duties were imposed and therefore decided to stock up early. "The Chinese also imported fewer goods from the US as a result of the tariffs imposed by the US government" (Eugenio, Gopinath \& Adil, 2019).

The results show that importers pay most of the duties collected. These costs are often passed on directly to consumers in the USA. Other cases show the absorption of the duties by importers, resulting in lower profit margins. However, an additional increase in tariffs would most likely be passed on to consumers (Eugenio, Gopinath \& Adil, 2019).

In addition to imposing duties on imports from China, the Trump administration has also threatened Huawei, the largest Chinese technology company, with being cut off from the supply of processors and chips. The company is heavily dependent on network devices as well as software and semiconductors in smartphones. This dependence is one of the company's greatest weaknesses. However, the USA is also vulnerable in the technology sector (The Washington Post, 2019b). "Rare earths are a number of chemical elements found in the earth's crust that are vital to many modern technologies, including consumer electronics, computers and networks, communications, clean energy, advanced transportation, health care, environmental protection, national defence and many others" (Rare Earth Technology Alliance, 2019). The newspapers in China speculated whether the government could use rare earths as a means of exerting pressure on the USA in the current trade war. Between 2014 and 2017, the USA imported 80\% of its rare earths from China (Daly \& Singh, 2019).

\section{EU-China trade relations and the implications of the US-China trade war}

In August 2018, the EU Chamber of Commerce in China conducted a survey to assess the impact of the US-China trade dispute on European companies operating in China. 193 respondents from various sectors took part in the survey. Even companies that are neither American nor Chinese are feeling the effects of the trade war between China and the USA. Furthermore, the global supply chain is interrupted by the conflict. Most respondents said that the tariffs have a negative impact on both sides. In addition, almost $20 \%$ stated that new investments or expansions would be delayed. Direct effects affect margins and costs and are coupled with indirect effects that lead to a slowdown in economic growth, less trade and fewer jobs. So far, only a small proportion of European companies operating in China have taken drastic steps, such as changing suppliers or relocating. However, this is an annoying trend considering that the situation could deteriorate if further duties were imposed. The President of the EU Chamber of Commerce in China Mats Harbon said that "the impact of the trade war between the US and China on European companies in China is significant and predominantly negative." He also said that while the EU shared US concerns about unfair Chinese practices, the imposition of duties was dangerous (The European Union Chamber of Commerce in China, 2019).

\section{Chinese steel exports to the EU after the implementation of US tariffs}

The analysis in the previous sub-chapter has shown that Chinese exports to the EU in 2018 have increased compared to the previous year. However, trade between the two sides 
has been increasing for years. The question arises how the Voestalpine HPM Division is affected by this development. Therefore, this sub-chapter specifically examines how Chinese steel exports to the EU have developed.

In March 2018, Trump announced the decision to impose duties of $10 \%$ on aluminium imports and $25 \%$ on steel imports. The tariffs, which affect both the EU and other countries, came into force on 1 June, 2018 (Alosi \& Rocha, 2018). Although China exported less steel in 2018 than in 2017, the country is still the world's largest steel exporter. China accounted for $16 \%$ of global steel exports. The amount of steel that China exports is almost twice as large as that of the second largest exporter, Japan. However, when looking at the total value, steel accounted for only $2.2 \%$ of all goods exported in 2017. Chinese steel exports have increased significantly after 2009. Between 2009 and 2018, steel exports rose by almost $200 \%$ overall.

Between 2016 and 2018, crude steel production in China rose continuously. Production increased from 830 million tonnes to 928 million tonnes. In 2016, the percentage of steel production used for export was three times as high as in 2009, but since 2017, the share of exported production has declined to $7.2 \%$ in 2018 (U.S. Department of Commerce, 2019, p. 1-6). In 2018, official steel consumption in the EU increased by 3.3\%. In addition, steel imports have also increased. World steel trade has been severely affected by the measures imposed under Section 232 of the US Customs Code at a $25 \%$ duty rate. As a result, steel exports to the US fell, while EU steel imports increased sharply over the same period. The EU reacted to this with a steel safeguard measure to stop the flood of diverted steel flowing into the EU. The EU safeguard measures have so far had mixed results as steel imports have reached record levels. In 2018, imports were at their highest level since 2007 , as total steel imports increased by $13 \%$. A total of 29.3 million tonnes of finished products were imported. The countries of origin for steel imports into the EU are China, India, Russia, South Korea and Turkey. Together, these nations account for $65 \%$ of all steel imports into the EU (EUROFOR, 2019, p. 6).

The EU institutions received a letter from the bosses of the European steel industry saying that US tariffs were diverting steel to Europe. Since 2013, steel imports to the EU have doubled, although demand for steel has only risen slightly in the same period (Reuters, 2019e).

\section{Impact of the tariffs on the Voestalpine HPM Division}

The HPM department produces high performance metals, which are characterised by special material properties that make them more resistant and polishable. These products are used in the consumer goods industry, the automotive industry, the oil and gas industry and in power plant construction. In addition, the HPM Division is a major supplier of forged parts to the power generation and aviation industries (Voestalpine, 2019, p. 8).

On 1 June, 2018, the USA introduced a tariff of 25\% on steel and $10 \%$ on aluminium. This has already led to diversification effects in the global steel sector at the expense of Europe. The CEO of Voestalpine Wolfgang Eder said in an interview: "Europe has lost almost 5 million tonnes of steel, the USA has gained 2.3 million tonnes," and compared this year's development with 2017. According to Eder, Trump is ignoring the rules of the world trading system that have been in place for decades, which "leads to massive changes in international trade flows," adding that "the EU is acting weaker and smaller in international trade disputes than it actually is."

In the last four years, Voestalpine has invested around 1.4 billion US dollars in the USA and employed around 3000 people in the country. The company uses three different strategies to fight the US duties:

- $\quad$ The first strategy is to pass on the additional costs to consumers.

- In addition, the company submitted around 5500 requests for exemption from the tariffs. 2950 of the 3300 responses were positive. However, the important decision on the exemption of seamless steel tubes is still pending.

- $\quad$ The third option is to relocate production, for example from the USA to Mexico, where the Group already employs 565 people at twelve locations. However, the problem is the increased minimum hourly wages and the requirements for minimum value added.

The new US trade agreement with Canada and Mexico, USMCA (replacing NAFTA), "is generally welcome. The deviations from the previous agreement are not so great" (Industriemagazin, 2018a).

In July 2019, the Chinese Ministry of Commerce announced the imposition of anti-dumping duties on several stainless steel products from the EU, Japan, South Korea and Indonesia. The tariffs will be increased between $18.1 \%$ and $103.1 \%$. Fortunately, Voestalpine is only slightly affected. The share of the revenue concerned is only about 8 million euro. However, increasing trade defence around the world has a negative impact on the global economy.

The Voestalpine Group has around 30 sites in China with more than 3000 employees generating a turnover of EUR 552 million in the 2018/19 business year. In line with the 
Group's internationalisation strategy, around 200 million euro have been invested in the construction, expansion and modernization of sites in China over the past ten years (Industriemagazin, 2019b). Eder's warnings about the economic downturn and the trade conflict between the US and China were fully reflected at a recent press conference. The company's profit and sales have declined in the first quarter of 2019. All four divisions were faced with a decline in sales. Weak demand from the automotive industry had a particularly negative impact. While other steel producers have long been struggling with overcapacities from China and are exposed to the pressure of consolidation on the European market, Voestalpine has so far been able to set itself apart from its competitors. However, the lead has now been exhausted: the high purchase prices for the iron ore needed for production, combined with the low steel selling prices, are increasingly becoming the subject of (Die Presse, 2019).

\section{Empirical Analysis}

Empirical research is a combination of quantitative and qualitative research. The first part of the empirical research involved conducting the quantitative analysis, followed by the qualitative analysis of the expert interviews evaluation. The qualitative part was used as the last step of the empirical research to create the possibility of using the results of the previous steps in the discussion with the experts.

The approach is also subject to some limitations:

- $\quad$ The trade war was an ongoing topic between July 2018 and December 2019, and new developments often took place on a daily basis. Certain information or findings can become outdated within a short time.

- A further restriction concerns the expert interviews. The trade war is an issue that mainly affects China and the USA. However, some of the experts interviewed had more information from a Chinese perspective as they work in China and one of the experts is Chinese. None of the interview partners currently works in the USA to provide up-to-date information on this perspective.

- The third limitation concerns the impact of the trade war on the HPM division of Voestalpine. Only limited public information is available. Therefore, the paper also examines the effects on the entire company and not only the effects on the HPM department.

- For the quantitative analysis, the price index of all steel imports was used. However, steel is a broad category consisting of many different products. Due to time constraints, the impact on steel was analysed without further subdividing steel into specific products.

\section{Quantitative research}

For the quantitative part of the empirical research, an analysis of the price elasticity of imports from China to the USA was carried out. In addition, this investigation also examines the development of imports from China into the USA. The aim of the quantitative research was to contribute to answering the following research question: How is Voestalpine HPM affected by the trade war between the USA and China?

Price elasticities are an important analytical tool in international trade and their usefulness is undeniable. This analysis is based on the model used in "Income and Price Elasticities World Trade" by Houthakker and Magee (1969).

Under certain conditions, the income elasticities of import demand and the income elasticity of export demand of each country strongly influence the change in trade balance over time. The balance of trade between two countries can change if "their respective income elasticities of demand for exports from the other country are different," even if prices remain constant and income growth is the same in both countries. Imports will grow much faster than exports if the income elasticity of demand for their imports is higher than the income elasticity of demand for exports. This will put pressure on the country's exchange rate and slow income growth may not be sufficient to avoid balance of payments imbalances leading to a deterioration in the trade balance (Houthakker \& Magee, 1969, p. 111).

Customs duties levied on goods increase their prices. The question arises whether this will lead to a change in demand for these goods. The tool used to perform this analysis was Stata. The results are presented in Figure 1. The period between January 2010 and December 2018 has been analysed (108 months), as no relevant data are currently available after this period. For this analysis, the consumer price index and the price index of all steel imports were used. The data for the quantitative analysis was collected by the "Bureau of Labour Statistics", the "UN Comtrade Database" and the "Federal Reserve Bank of St. Louis" to analyse the following hypothesis: The price increase leads to a reduction in import demand.

The number of observations refers to the number of months analysed. The $\mathrm{R}$ square measures the amount of the total variance explained in the model. The coefficient on the variable of interest is -0.351 , which means that a $1 \%$ price increase leads to an average reduction of $0.35 \%$ in imports. After checking for heteroskedasticity and autocorrelation using robust standard errors (White, 1980, pp. 817-818), it can be concluded from our t-statistic of -3.67 that we can reject the hypothesis that there is no effect at a highly significant level $(\alpha=0.01)$. A more advanced model could be 
Figure 1. Analysis results

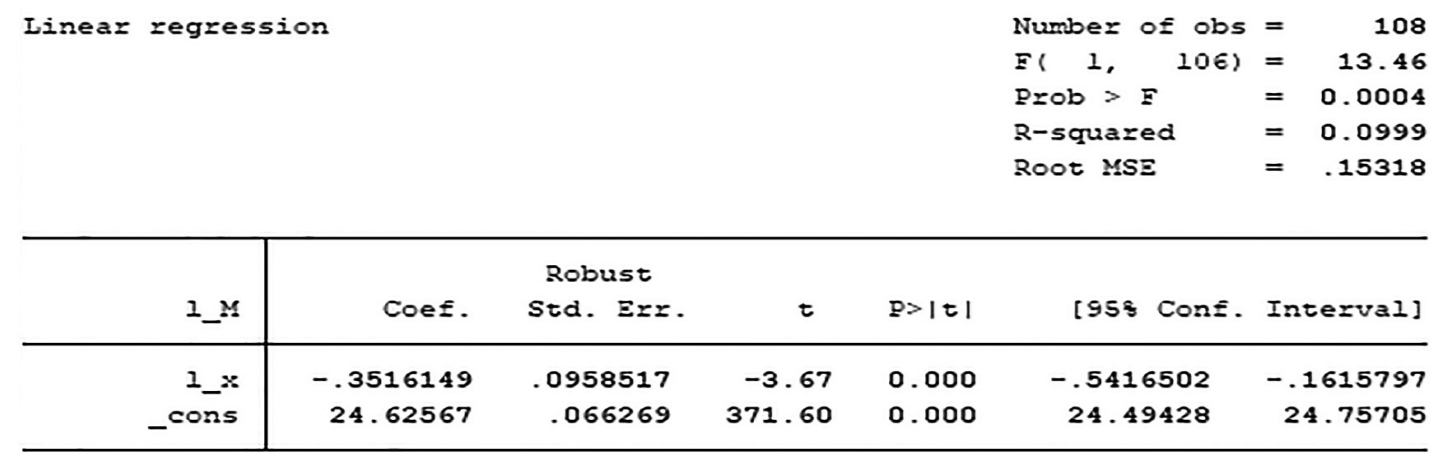

Source: Own illustration. The data for the quantitative analysis was gathered from the "Bureau of Labor Statistics", the "UN Comtrade Database" and the "Federal Reserve Bank of St. Louis".

Figure 2. Development of Chinese imports to the US

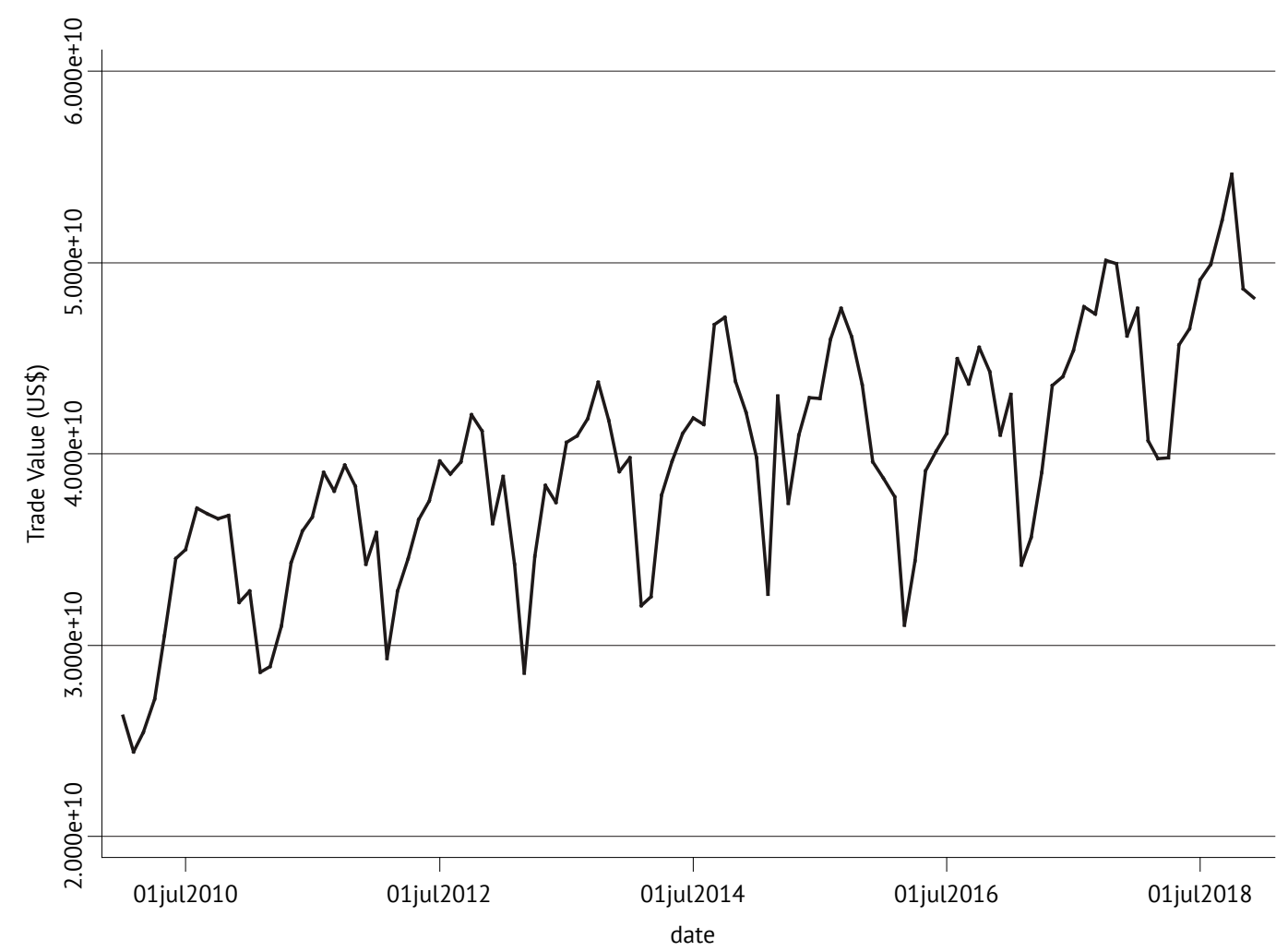

Source: Own illustration. The data for the quantitative analysis was gathered from the "Bureau of Labor Statistics", the "UN Comtrade Database" and the "Federal Reserve Bank of St. Louis".

constructed that could better explain the causalities, but this model shows that an increase in price has at least some effect to changes in demand.

Figure 2 shows the development of all Chinese imports into the U.S. from the beginning of 2010 to the end of 2018, and clearly shows that the total trade value of imports into the U.S. has increased dramatically over the last 8 years.
Figure 3 shows the development of the price index of all steel imports (compared to the consumer CPI price index) in the USA. CPI calculates "the weighted average of the prices of a basket of consumer goods and services, such as transport, food and medical care." The index shows how the price of each item in the shopping cart changes (Chen, 2019). The price index for steel imports does exactly the same, but only for steel products. 
Figure 3. Price index of steel imports

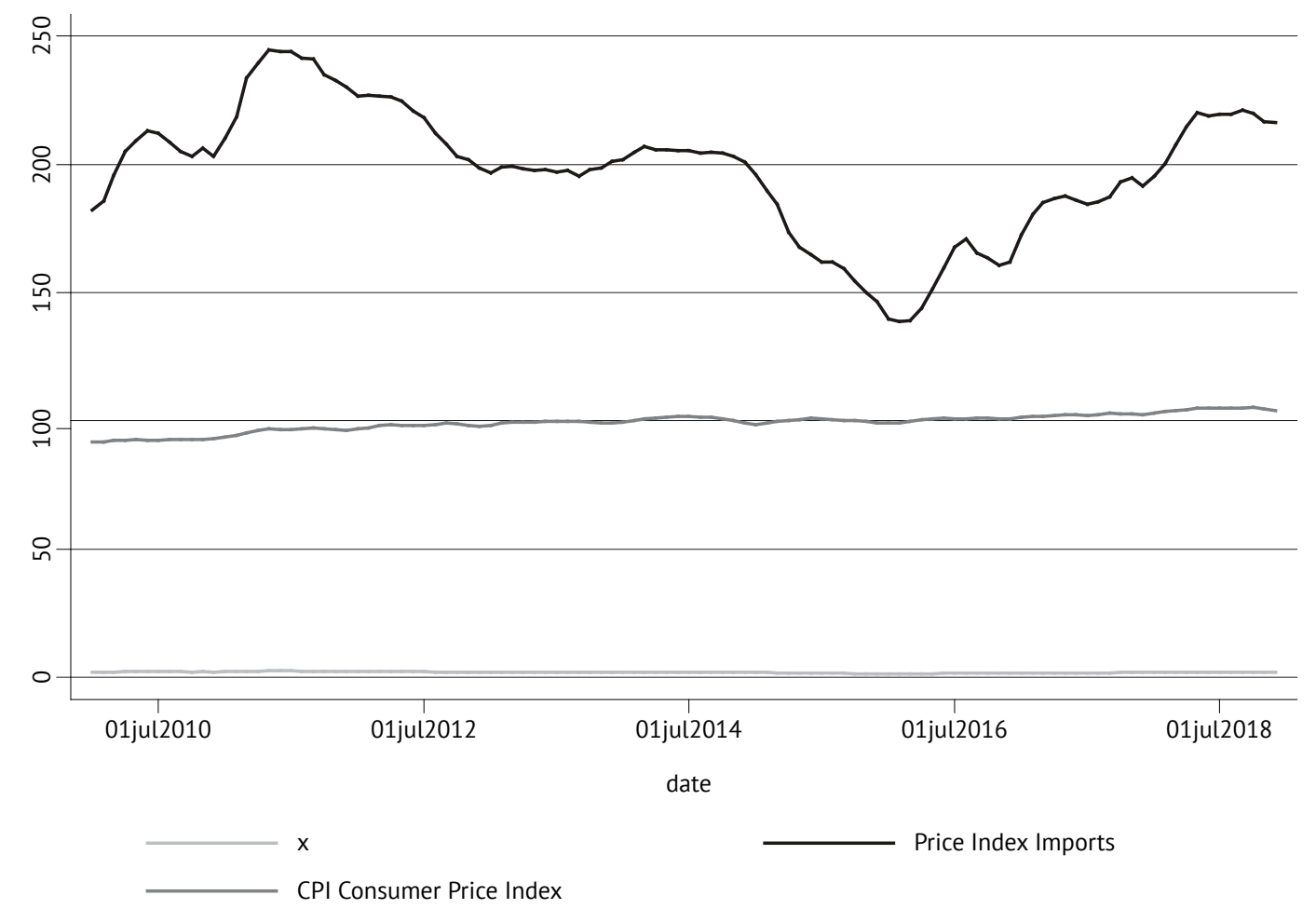

Source: Own illustration. The data for the quantitative analysis was gathered from the "Bureau of Labor Statistics", the "UN Comtrade Database" and the "Federal Reserve Bank of St. Louis".

A look at the indices allows the comparison of figures from different years to see whether prices are falling or rising. "The government can take measures to counteract the undesirable effects of price change" (Suman, n.d.). While the CPI index has remained relatively stable in recent years, the price index of steel imports has increased sharply over the same period.

\section{Qualitative research}

Seven interviews were conducted with the experts, six of which are Austrian and one Chinese. The interview partners are the following:

I1: Austrian expert at an Austrian trade organisation in Beijing,

I2: Austrian expert who works as a lecturer at the $\mathrm{FH}$ Joanneum,

I3: Austrian expert at an Austrian trade organisation in Hong Kong,

I4: Austrian expert working at a research institute,

15: Chinese expert working as a professor in China and Austria,

I6: Austrian expert at an Austrian trade organisation,

I7: Austrian expert working as a professor at the University of Graz.
The questions asked were the following:

Q1.) What general effects of the trade war between the USA and China are already being felt?

Q2) Do you believe that the trade war will intensify in the future or will both parties succeed in defusing the conflict?

Q3) Both sides have introduced new tariffs in recent months.

3a) How do the tariffs affect companies in the countries observed?

3b) How are consumers affected by the tariffs?

Q4) In your opinion, could there be other developments besides tariffs that would have negative consequences for companies?

Q5)Are there positive effects of the imposition of duties?

Q6)Are there opportunities for companies to benefit from the tariffs?

Q7) What strategy can international companies use to mitigate the effects of tariffs?

Q8) What strategy are companies pursuing in the current trade war between the USA and China to reduce the negative effects?

Q9) What strategy would you recommend specifically for companies in the steel industry? 
The interviews each lasted between 22 and 60 minutes, with an average duration of about 35 minutes. The interviews were conducted by telephone or Skype. Due to the qualitative nature of the interviews, they cannot be recorded statistically. The entire methdology underlying the interviews follows Mayring's approach (Mayring, 2016, p. 71).

Q1: An increase in uncertainty and unpredictability (I1, I2, I3) and negative effects on the Chinese economy (I2, I4, I7) were the most common responses. Companies will try to act confidently in public and show no signs of nervousness (I2). Increased uncertainty could also lead to new investments being postponed. However, according to a survey in 2018, Austrian companies operating in China have indicated that they have not felt any significant influence so far (I1). Many American companies rely on parts from China to manufacture their products, and some of them may go out of business unless they find a new source for these goods (I5). As a result of the trade war (I4), China is experiencing the slowest growth in decades. Moreover, the dispute is leading to massive changes in trade flows (I4). Despite tariffs on Chinese imports, the US trade deficit with China has not changed (I7). Other effects include the impact on US and Chinese companies (I5) and the potential damage to the global economy (I6, I7).

Q2: Almost all experts said that it depends on what the Americans do and President Trump will do (I2, I3, I4, I5, I6, I7). The consensus is that China wants to end the trade war and has no interest in further escalation. The actions of President Trump will, however, carry great weight, and 2020 elections could have a significant impact (I6, I7). However, the trade war cannot be ended until the USA is ready to treat China equally (I5).

Q3a: Many experts said that the affected companies, as suppliers or buyers, are struggling with falling profit margins (I2, I4, I5, I6). Some companies are trying to diversify, either by changing their supply chains or by looking for new markets (I1, I6). The trade war creates a difficult environment for companies that do not operate globally (I3). American products will lose competitiveness due to higher prices (I5). However, the impact often depends on the specific companies (I7).

Q3b: All experts said that consumers have to pay higher prices for imported goods. Consumers will lose purchasing power (I4) and certain products will subsequently no longer be available (I6). An example of this is the increase in the price of washing machines in the USA (I7).

Q4: The global economy will grow more slowly and the general outlook is less positive (I1, I2), companies around the world will feel the effects of the trade war (I5) and companies are facing increased uncertainty (I3). In addition, the USA presents itself as an unreliable trading partner and violates principles that have been valid for decades, such as the free movement of goods and cost advantages (I4). American companies will suffer long-term consequences because necessary structural changes will not be made, as they do not currently have to compete fairly (I6).

Q5 and Q6: Most experts said that there could be at least some positive effects. Companies operating in customs-protected sectors can benefit from them (I2, I4, I6, I7). Moreover, undertakings protected by tariffs will be less exposed to competition (I4). There could also be indirect effects through changes in consumer behaviour (I1), and companies that already produce locally will have an advantage (I3). Tariffs can also help developing countries to build up domestic industries without facing strong external competition (I6). However, one interviewee said that there are no positive effects of tariffs, other than the fact that governments collect some money through tariffs (I5) and that consumers and businesses are concerned about the trade war.

Q7: The experts mentioned a variety of strategies. One way to mitigate the negative effects is to restructure the supply chain by relocating procurement or changing the production site (I3, I4, I5, I7). Companies must also be able to follow new developments and react quickly. (I1). Another possible strategy is an attempt to influence decision-makers (I2). Having more than one supplier also reduces the geopolitical risk (I3). In addition, companies can take advantage of intra-company trade if they operate globally (I4). Companies should conquer new markets, which can be achieved through technological superiority (I6).

Q8: Although supply chain restructuring is a possible option, companies will not implement this strategy immediately and will first evaluate their options, but some companies are more flexible than others (I3, I6). Some Chinese exporters are lowering their prices to compensate for the duties (I4). Some American companies may relocate their production facilities away from China (I5), while Chinese companies export their goods to the US via Vietnam (I7).

Q9: Evaluating good strategies for steel companies is difficult and depends heavily on the company in question (I2, I4, I6, I7). In addition, the strategies also depend on the company's products (I6) and the company's competitors and customers, as well as the location (I7).

One issue that came up very frequently in all experts interviews was the positive and negative impact of the ongoing trade war between the US and China on the EU and its Member States. The first possible positive effect mentioned by one interviewee is that European products are substitutes 
for American products on the Chinese market. One indication of this could be the increase in Austrian exports to China since the beginning of the dispute (I1). The European countries are interested in filling the gaps created by the trade war. The European agricultural industry already sees benefits. However, both China and the US are important markets and trading partners for the EU. The effects of the trade war may therefore also have a negative impact on the EU (I4). It is important to note that Europe has lost much industry to China in the past (I2). Another potential problem for the EU is the fact that it may be increasingly targeted by the US and face new tariffs (I3). This would cause major problems for countries like Austria which export a great deal (I6). Chinese companies are shifting part of their investment from the US and may choose Europe as a new destination (I5). Certain goods that are currently produced outside Europe may in future be produced in Europe. The EU is an area with a high demand for products. The Member States alone are too small to exert influence, but the EU is large enough to play an important role on the international stage and as a trading bloc (I7). Protectionism and resistance to free trade (TTIP and so on) are on the rise. Brexit is a good example of this. Such a situation is dangerous because it has its own dynamics (I7).

\section{Discussion and Conclusion}

The final chapter of this paper brings together the results and findings of the theoretical analysis and the empirical research that will help answer the three research questions outlined at the beginning of the paper. This process will add to the existing literature new insights into the trade war between China and the US and its effects, strategies to mitigate the negative effects of tariffs, and discussions on optimal strategies for companies in the steel industry.

The relationship between China and the USA lacks trust. China's politicians are convinced that the USA is trying to stop its rise to world power. American politicians are now concerned about the theft of trade secrets and technology (Liebertahl \& Wang 2012, p. vi-ix). Tensions between the two countries have steadily increased and have now reached a point where they are difficult to resolve. US companies operating in China often complained about the bad treatment in China. Some companies had their technology stolen or were forced to give it away. The USA tried to raise this issue with the WTO, but was unsuccessful. The WTO mechanism to avoid bilateral trade disputes lost its effectiveness as the US made less use of the complaint procedure to resolve such issues. After China's accession to the WTO in 2001, many other trade barriers - instead of tariffs - were used by both countries against each other (Bown, 2019, p. 2-3). Moreover, there are already several visible effects of the current war. Although global growth has so far been slightly impaired, recent escalations could change this and even disrupt supply chains worldwide (Eugenio, Gopinath \& Adil, 2019).

The trade war is causing great uncertainty among companies, which in certain cases has led to the postponement of planned investments. China's growth has slowed down and this could further affect the global economy. Companies, on the other hand, are facing falling profit margins, and American companies using parts from China could lose competitiveness due to higher prices. Some companies are diversifying their supply chain to be less dependent on production in China and are trying to establish themselves in new markets to compensate for their losses.

Despite the tariffs imposed by the USA on Chinese goods, the trade deficit with China has hardly changed (I7). Meanwhile, the dispute is having a negative impact on producers and consumers (Eugenio, Gopinath \& Adil, 2019). This development was also confirmed by every survey expert who said that consumers are now paying higher prices for goods. Furthermore, certain products are no longer available to consumers.

The trade war between July 2018 and December 2019 also leads to massive changes in international trade flows. Steel serves as a good example. While steel imports from the USA fell sharply, more and more steel is finding its way into the EU (Industriemagazin, 2018a).

\section{Effects of the trade war on Voestalpine HPM}

In March 2018, the US introduced a 25\% tariff on steel imports from the EU and many other countries (Alosi \& Rocha, 2018). US tariffs have a major impact on global steel trade. While more and more steel is flowing into the EU, steel imports from the USA have declined. The EU has taken safeguard measures to protect its domestic industry, but the results so far are not impressive and steel imports have reached a new peak (EUROFOR 2019, p. 6).

Managers of steel producers in Europe sent a letter to the EU warning that steel would be diverted to Europe because of US tariffs (Reuters, 2019e). Steel products were also targeted by China as the country increased tariffs on stainless steel products. While this development only affects Voestalpine to a minor extent, the increasing protectionism in many countries is having an impact on the global economy (Industriemagazin, 2019b).

Voestalpine's profit fell by 60\% in the first quarter of 2019, and the revenues of all four divisions declined. Overcapacities from China and the declining demand from the automotive industry are causing problems for the company (Die Presse, 
2019). The Voestalpine HPM Division is also feeling the negative effects of the trade war. The division's main product segment in China, tool steel, is affected by lower tool exports from China to the USA. International suppliers of tool steel are concentrating more on the European market due to the increased protectionist stance of the USA. The division is also feeling the effects of the reluctance of consumers in China to buy new cars in the wake of the ongoing trade war with the USA (Voestalpine 2019, pp. 72-73).

The price index of steel imports to the USA has risen significantly in the last two years, even before the current tariffs imposed by the Trump administration came into force in March 2018. Therefore, companies using steel as an input for their products are now faced with higher costs for the production of their goods. Rising costs mean that these producers will have to raise their prices to achieve the same profits as before. The analysis in the quantitative part showed a price elasticity of $-0.35 \%$ for all imports, which means that a price increase of $1 \%$ on average leads to a $0.35 \%$ reduction in imports. This means that consumers are not prepared to pay higher prices at least for everyday goods.

\section{Strategies to mitigate the negative effects of tariffs}

One example of a company suffering the effects of the trade war is GE that estimates the cost of tariffs at up to $\$ 400$ million (Leonard, 2019). Companies like GE have a variety of options to try to reduce the cost of tariffs depending on their products and markets. One of their strategies is to replace the components affected by tariffs with components that are not subject to tariffs. In addition, they GE purchased certain goods before the customs duties came into force (Leonard, 2019).
Another possible strategy for companies is to change their supply chain (Business Insider, 2019) by shifting procurement and having more than one supplier for important goods or by importing from elsewhere. The establishment of new sourcing sites is the strategy advocated by several experts from the clothing and footwear industry (Butler-Young, 2019). Companies can also set up production facilities in other countries in order to avoid customs duties. It is also important for companies to be flexible and to be able to make decisions based on new developments and to talk to decision-makers.

Conquering new markets by diversifying the product portfolio is also a way for companies to compensate for problems in other markets. A reduction in the cost of tariffs is also possible through the "first sale rule". However, this requires a middleman and multiple sales of a product before it is brought into a country where duties apply (Zhang, 2019).

The choice of the best strategy depends very much on a specific company. In addition, the best strategy also depends on the industry, the products of a company and the competitors and customers of a company.

Voestalpine, just like GE, implemented several strategies to resist the tariffs imposed by the USA. The company has completed over 5,000 applications for exclusion of products from the duties. The requests were granted in the majority of cases. It can therefore be assumed that this strategy is working well for the company. In addition, Voestalpine passes on part of the cost of the tariffs to its consumers. Last but not least, the company has the option of relocating parts of its production from the USA, for example to Mexico (Industriemagazin, 2018a).

\section{References}

Alosi, A., \& Rocha, F. (2018). US trade tariffs on imported steel and aluminium become effective. Retrieved from www.europeansources.info: https://www.europeansources.info/record/us-trade-tariffs-on-imported-steel-and-aluminium-become-effective/

Bown, C. P. (2019). The 2018 US-China Trade Conflict After 40 Years of Special Protection. Retrieved from https://piie.com/system/files/ documents/wp19-7.pdf https://doi.org/10.2139/ssrn.3378791

Brander, J. A., \& Spencer J., B. (1985). Export Subsidies and International Market Share Rivalry. Journal of International Economics, 18(1), 83-100. https://doi.org/10.1016/0022-1996(85)90006-6

Business Insider. (2019). Business leaders are expressing frustration and uncertainty about the US-China trade war. Retrieved from www. businessinsider.de: https://www.businessinsider.de/trade-war-us-china-dispute-took-executives-by-surprise-2019-5? r=US\&IR=T

Butler-Young, S. (2019). How to Legally Avoid Tariffs: The Critical Rules Every Shoe Brand Should Know. Retrieved from www.footwearnews. com: https://footwearnews.com/2019/business/trade/how-to-avoid-tariffs-china-trade-war-1202798574/

Die Presse. (2019). Gewinneinbruch von 60 Prozent bei Voestalpine. Retrieved from www.diepresse.com: https://diepresse.com/home/ wirtschaft/economist/5670553/Gewinneinbruch-von-60-Prozent-bei-Voestalpine

Eugenio, C., Gopinath, G., \& Adil, M. (2019). The Impact of US-China Trade Tensions. Retrieved from www.blogs.imf.org: https://blogs.imf. org/2019/05/23/the-impact-of-us-china-trade-tensions/

EUROFOR. (2019). 2019 Annual report.

Govinfo. (2018). TRADE ACT OF 1974. Retrieved from http://legcounsel.house.gov/Comps/93-618.pdf

Houthakker, H., \& Magee, S. (1969). Income and Price Elasticities in World Trade. The Review of Economics and Statistics, $51(2)$, pp. 111 -125. Retrieved from : https://www.jstor.org/stable/1926720 https://doi.org/10.2307/1926720 
Industriemagazin. (2018a). Handelskonflikt, Strafzölle und der Kurs der Voest. Retrieved from www.industriemagazin.at: https://industriemagazin.at/a/handelskonflikt-strafzoelle-und-der-kurs-der-voest

Krugman, P. R. (1987). Is Free Trade Pass_e? Journal of Economic Perspectives, 1(2), 131-144. https://doi.org/10.1257/jep.1.2.131

Larry, D. Q, Chaoqun, Z., \& Xing, W. (2019). An analysis of the China-US

trade war through the lens of the trade literature. Economic and Political Studies, 7(2), 148-168. https://doi.org/10.1080/20954816.201 9.1595329

Leonard, M. (2019). 8 strategies GE is using to mitigate tariff cost. Retrieved from www.supplychaindive.com: https://www.supplychaindive.com/news/8-strategies-ge-mitigate-tariff-cost-ISM/552270/

Liebertahl, K., \& Wang, J. (2012). Addressing U.S.-China Strategic Distrust. Retrieved from http://yahuwshua.org/en/Resource-584/0330_ china_lieberthal.pdf

Mayring, P. (2016). Einführung in die qualitative Sozialforschung. Weinheim: Beltz Verlag.

Noland, M. (1996). US-China Economic Relations. Retrieved from https://piie.com/publications/working-papers/us-china-economic-relations

Office of the United States Trade Representative. (2019a). Economy \& Trade. Retrieved from www.ustr.gov: https://ustr.gov/issue-areas/ economy-trade

Office of the United States Trade Representative. (2019b). The People's Republic of China. Retrieved from www.ustr.gov: https://ustr.gov/ countries-regions/china-mongolia-taiwan/peoples-republic-china

Rare Earth Technology Alliance. (2019). What Are Rare Earths? Retrieved from http://www.rareearthtechalliance.com: http://www.rareearthtechalliance.com/What-are-Rare-Earths

Reuters. (2019a). Apple explores moving 15-30\% of production capacity from China: Nikkei. Retrieved from www.reuters.com: https://www. reuters.com/article/us-apple-china-restructuring-idUSKCN1TKOXN?utm_campaign=trueAnthem:+Trending+Content\&utm_content

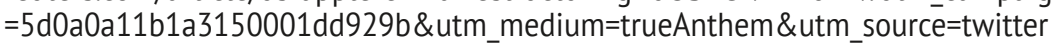

Reuters. (2019b). U.S.-China trade talks: where they are and what's at stake. Retrieved from www.reuters.com: https://www.reuters.com/ article/us-usa-trade-china-talk-explainer/explainer-u-s-china-trade-talks-where-they-are-and-whats-at-stake-idUSKCN1TT2JF

Reuters. (2019c). Timeline: Key dates in the U.S.-China trade war. Retrieved from www.reuters.com: https://www.reuters.com/article/ us-usa-trade-china-timeline/timeline-key-dates-in-the-us-china-trade-war-idUSKCN1SE2OZ

Reuters. (2019d). Who pays Trump's tariffs, China or U.S. customers and companies? Retrieved from www.reuters.com: https://www.reuters. com/article/us-usa-trade-china-tariffs-explainer/who-pays-trumps-tariffs-china-or-u-s-customers-and-companies-idUSKCN1SR1Ul

Reuters. (2019e). EU needs to act on steel imports in wake of U.S. tariffs: industry. Retrieved from www.reuters.com: https://www.reuters. com/article/us-steel-europe/eu-needs-to-act-on-steel-imports-in-wake-of-u-s-tariffs-industry-idUSKCN1T519B

Reuters. (2019f). EU agrees to extend steel import curbs until 2021. Retrieved from www.reuters.com: https://www.reuters.com/article/ us-eu-trade-steel/eu-agrees-to-extend-steel-import-curbs-until-2021-idUSKCN1PA1VF

Spencer, B. J., \& James A. B. (1983). International R\&D Rivalry and Industrial Strategy. The Review of Economic Studies, 50 (4): $707-722$. https://doi.org/10.2307/2297771

Stiglitz, J. E. (2018). Rethinking Globalization in the Trump Era: US-China Relations. Frontiers of Economics in China, 13 (2), $133-146$.

Suman, S. (n.d.). Price Index: Meaning, Uses and Importance. Retrieved from http://www.economicsdiscussion.net: http://www.economicsdiscussion.net/price/price-index/price-index-meaning-uses-and-importance/12722

The European Union Chamber of Commerce in China. (2019). European Chamber survey and analysis on US-China tariff effect. Retrieved from www.europeanchamber.com: https://www.europeanchamber.com.cn/en/press-releases/2711/european_chamber_survey_ and_analysis_on_us_china_tariff_effects

The Washington Post. (2019). Rare Earths, the U.S.-China Trade War and Your Phone. Retrieved from www.washingtonpost.com: https:// www.washingtonpost.com/business/rare-earths-the-us-china-trade-war-and-your-phone/2019/05/20/b4eabdc6-7b43-11e9b1f3-b233fe5811ef_story.html?utm_term=.d91209c02d0e

U.S. Department of Commerce. (2019). Steel Exports Report: China.

United States International Trade Commission. (n.d). Understanding Safeguard Investigations. Retrieved from www.usitc.gov: https:// www.usitc.gov/press_room/us_safeguard.htm

Voestalpine. (2019). ANNUAL REPORT 2018/19.

White, H. (1980). A Heteroskedasticity-Consistent Covariance Matrix Estimator and a Direct Testfor Heteroskedasticity. Econometrica, 48(4), 817-838. https://doi.org/10.2307/1912934

Zhang, Z. Y. (2019). The First Sale Rule: A Way to Reduce Exposure to US-China Tariffs? Retrieved from www.china-briefing.com: https:// www.china-briefing.com/news/first-sale-rule-us-china-trade-war/ 


\section{Trgovinska vojna med ZDA in Kitajsko: vpliv na avstrijsko podjetje $v$ jeklarskem sektorju}

\section{Izvleček}

Namen članka je podati informacije o trgovinski vojni med Kitajsko in ZDA. Članek analizira posledice trgovinskega spora, razpravlja o vplivu na avstrijsko podjetje $v$ jeklarskem sektorju, daje pregled mogočih strategij, s katerimi lahko podjetja zmanjšajo negativne učinke carin, in razpravlja o strategijah, ki predstavljajo dobre izbire za podjetja v jeklarski industriji. Uporabljena metodologija obsega teoretično in empirično raziskavo, ki temelji na kvantitativni analizi, vključujoč intervjuje s strokovnjaki. Rezultati kažejo, da je bila trgovinska vojna med Kitajsko in ZDA v popolnem zamahu do januarja 2020. Učinki ne zadevajo samo vključenih strani, temveč tudi druge, kot npr. Evropsko unijo. Podjetja lahko uporabijo različne strategije, da bi ublažila negativne učinke trgovinskih vojn. Najboljša strategija za podjetje temelji na njegovi strukturi, njegovih proizvodih in njegovih konkurentih. Članek prispeva nove vpoglede k obstoječi literaturi o trgovinski vojni med Kitajsko in ZDA in njenih učinkih, o strategijah za blaženje negativnih učinkov carin ter k razpravam o optimalnih strategijah za podjetja v jeklarski industriji.

Ključne besede: trgovinska vojna, Kitajska, ZDA, carine, EU, strategije 